\title{
Roles of Stem Cell Antigen-1 in the Pulmonary Endothelium
}

\author{
Jun Maeda, Keiko Uchida, Kazuki Kodo, \\ and Hiroyuki Yamagishi
}

\author{
Keywords \\ Resident progenitor cell $\cdot$ Pulmonary vessels $\cdot$ Sca- $1 \cdot$ Angiogenesis
}

There is growing evidence that resident progenitor cell populations exist in murine lung tissues and differentiate into a mesenchymal cell lineage [1, 2]. Stem cell antigen-1 (Sca-1) is a cell surface glycoprotein, initially found in murine bone marrowderived stem cell subtypes, such as hematopoietic stem cells. Some studies showed Sca-1 expression in the pulmonary vascular endothelium of adult murine lungs [3], while a subset of Sca-1-expressing cells formed vascular-like structures under specific conditions [1].

We previously performed DNA microarray analysis using murine lung cells positive for vascular endothelial marker, CD31, selected by fluorescence-activated cell sorting (FACS) at embryonic and postnatal stages. Sca-1 was found to be more robustly expressed in postnatal pups than in embryos (Uchida K, unpublished observation), suggesting that a subset of Sca-1-expressing cells may be related to the formation of the capillary network during later development.

First, we performed immunohistochemistry using eight-week-old murine lung sections where Sca-1 immunostaining was found in the vascular wall of pulmonary vessels and alveolar capillaries. Some of these Sca-1-positive cells showed overlapping expression with vascular endothelial marker, vWF. Cell populations were then

\footnotetext{
J. Maeda $\cdot$ K. Uchida $\cdot$ K. Kodo

Department of Pediatrics, Keio University School of Medicine, Shinjuku, Tokyo, Japan

H. Yamagishi $(\square)$

Division of Pediatric Cardiology, Department of Pediatrics,

Keio University School of Medicine, Tokyo, Japan

e-mail: hyamag@keio.jp
} 


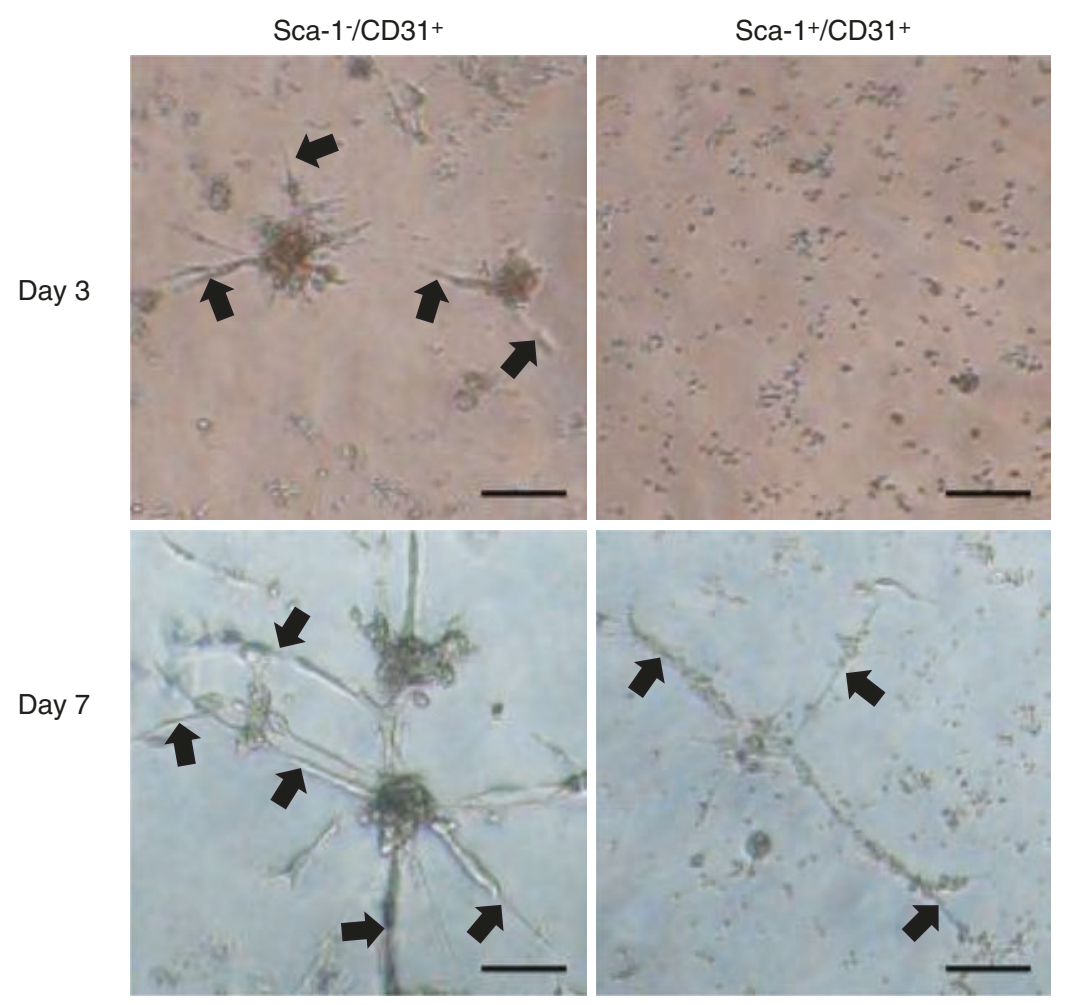

Fig. 10.1. The tube formation assay. The tube formation (arrows) reflecting angiogenesis is more robustly observed in Sca-1 (-) CD31 (+) cells than in Sca-1 (+) CD31 (+) cells. Scale bars, $100 \mu \mathrm{m}$

isolated from whole-lung cells by FACS, using antibodies for Sca-1 and CD31, following the depletion of CD45-positive cells. We investigated the tube formation ability of these sorted cells cultured in endothelial growth media and found that Sca-1 (-) CD31 (+) cells were more robust in tube formation than Sca-1 (+) CD31 $(+)$ cells (Fig. 10.1).

These results suggest that though Sca-1 (+) CD31 (+) cells form vascular tube structures, they have lower tube formation activity than Sca-1 (-) CD31 (+) cells. Sca-1 may possibly repress angiogenesis activity in the endothelial cells and potentially make progenitor cell populations stay resident in adult murine lungs. Further analysis would delineate the physiological function of Sca-1 in developing lungs through embryonic to adult stages.

Acknowledgment This work was supported by JSPS KAKENHI Grant Number JP16K10074 to J.M. 


\section{References}

1. Summer R, Kotton DN, Liang S, et al. Embryonic lung side population cells are hematopoietic and vascular precursors. Am J Respir Cell Mol Biol. 2005;33:32-40.

2. McQualter JL, Brouard N, Williams B, et al. Endogenous fibroblastic progenitor cells in the adult mouse lung are highly enriched in the Sca-1 positive cell fraction. Stem Cells. 2009;27:623-33.

3. Kotton DN, Summer RS, Sun X, et al. Stem cell antigen-1 expression in the pulmonary vascular endothelium. Am J Physiol Lung Cell Mol Physiol. 2003;284:L990-6.

Open Access This chapter is licensed under the terms of the Creative Commons Attribution 4.0 International License (http://creativecommons.org/licenses/by/4.0/), which permits use, sharing, adaptation, distribution and reproduction in any medium or format, as long as you give appropriate credit to the original author(s) and the source, provide a link to the Creative Commons license and indicate if changes were made.

The images or other third party material in this chapter are included in the chapter's Creative Commons license, unless indicated otherwise in a credit line to the material. If material is not included in the chapter's Creative Commons license and your intended use is not permitted by statutory regulation or exceeds the permitted use, you will need to obtain permission directly from the copyright holder. 